\title{
Amoco Oil Co. v. Environmental Protection Agency: Common Law Standards Limit Agency Rulemaking
}

\author{
In Amoco Oil Co. v. Environmental Protection Agency (Amoco
} II), ${ }^{1}$ the District of Columbia Circuit Court of Appeals struck down portions of an Environmental Protection Agency (EPA) regulation ${ }^{2}$ that it found to be in conflict with common law rules of vicarious liability. The invalidated clause would have imposed civil penalties upon refiners for lead contamination of unleaded gasoline sold at retail outlets owned and directly supplied by them, but leased to independent operators. ${ }^{3}$ The court found that the clause altered the common law relation of lessor and lessee because it imposed liability upon refiners for contamination caused by retailer negligence without regard for "the degree of control exerted by the refiner over the retailer-lessee." 4 Because the

1. 543 F.2d 270 (D.C. Cir. 1976).

2. 40.C.F.R. $\$ 80.23$ (1975).

3 Distribution of gasoline follows three basic patterns. First, many retail outlets receive gasoline directly from the refiner. These operations are usually owned by the refiner and leased to the retail operator. See Comment, Liability of Oil Companies for The Torts of Service Station Operators, 7 LAND AND WATER L. REv. 263, 265 (1972). Second, the refiner may sell gasoline in bulk lots to middlemen-called jobbers-who in turn retail the product at their own stations, ones that usually display the refiner's trademark. Finally, independent marketers may purchase gasoline from either independent or branded refiners, and market the product under their own name. EPA Proposed Restrictions on Use of Unleaded Gasoline, 39 Fed. Reg. 13,175 (1974) [hereinafter cited as EPA Proposed Restrictions].

The EPA regulations impose blanket vicarious liability for lead contamination on all brand name refiners:

Where the corporate, trade, or brand name of a gasoline refiner or any of its marketing subsidiaries appears on the pump stand or is displayed at the retail outlet or wholesale purchaser-consumer facility from which the gasoline was sold, dispensed, or offered for sale, the retailer or wholesale purchaser-consumer, the reseller (if any), and such gasoline refiner shall be deemed in violation.

40 C.F.R. $\$ 80.23$ (a) (1) (1975). Vicarious liability does not attach for contamination caused by retailers who are not directly supplied lessees: "The refiner shall not be deemed in violation if he can demonstrate . . . that the violation was caused by the action of a retailer who is supplied directly by the refiner . . . and whose assets or facilities are not substantially owned, leased or controlled by the refiner . ..." 40 C.F.R. $\$ 80.23$ (b)(2) (1975). The net effect of these two sections is to hold refiners liable for all contamination caused by their directly supplied lessees. Other sections exempt the refiner from liability for contamination caused by distributors in the indirect and independent distribution chains, common carriers transporting gasoline, and wholesale purchaser-consumers. 40 C.F.R. $\$ 80.23$ (b)(2) (v-vii) (1975).

4. 543 F.2d 270, 276 (D.C. Cir. 1976). 
congressional grant of authority to EPA did not evince "specific intent" to create a "new tort," the court reasoned that by altering the common law rule the agency had acted beyond its powers, and that the regulation was therefore "arbitrary" and voidable within the meanimg of section 706 of the Adıninistrative Procedure Act (APA). ${ }^{6}$

The court's argument that the EPA regulation was contrary to common law principles is clearly incorrect on the facts before it. More iniportant, the reasoning of the opinion diverges sharply froin prior case law and reflects a view of the regulatory process that would substantially alter the traditional relationship between courts, regulatory agencies and Congress. Earher cases strongly suggest that regulatory standards that conflict with coinmon law rules are not arbitrary insofar as they better proinote the policies underlying the agency's enabling legislation. ${ }^{7}$ The Amoco II court, in contrast, held that in the absence of clearly expressed congressional intent to alter a common law rule, agency alteration of that rule is arbitrary whether or not it serves the apparent legislative policy. The court's holding, however, would force an unacceptable choice between intrusive judicial inquiry into agency rulemaking and diminished flexibility in the rulemaking process. This Note will explain the history of the Amoco II controversy and will then consider critically the court's suggested approach to regulatory standards that deviate froin the common law.

\section{HISTORY OF THE Amoco CONTROVERSY}

Lead-based additives in gasoline sharply limit the effectiveness of the catalytic converters used as pollution control devices in new automobiles. Lead coats and renders ineffective the platinuin surfaces used in these devices to convert pollutants into less harmful coinpounds. ${ }^{8}$ Since poisoning of catalytic converters can occur at relatively low levels of sustained lead contamination, strict control of gasoline purity is a necessity. In the 1970 Amendments to the Clean Air Act, ${ }^{10}$ Congress

\section{Id. at 275 .}

6. Id. at 279 .

7. See text accompanying notes $52-56$ infra.

8. For a discussion of the "poisoning effect" of leaded gasoline on catalytic converters see J. MCDermotT, Catalytic Conversion of Automobile Exhaust 149 (1971).

9. The automotive industry initially asserted the need for a lead contamination maximum of 0.03 gram per gallon of unleaded gasoline. The final EPA standards set a maximum limit of 0.05 gram per gallon, that was judged adequate to produce an average of 0.03 grams per gallon. Amoco Oil Co. v. EPA (Amoco I), 501 F.2d 722, 738, 741 n.47 (D.C. Cir. 1974).

10. 42 U.S.C. $\$ 1857$ (1970). 
gave the EPA authority to regulate fuels and fuel additives found to impair the effectiveness of emission control devices. ${ }^{11}$ Pursuant to this authority, the EPA promulgated regulations in 1973 that both require service stations with a substantial business volume to offer at least one grade of unleaded gasoline ${ }^{12}$ and prohibit the introduction of leaded gasoline into the converter-equipped cars. ${ }^{13}$ The regulations held refimers strictly and vicariously liable for all violations by retailers displaying their trademark, "irrespective of whether any refimer, distributor, or retailer, or the employee or agent of any refimer, distributor, or retailer may have caused or permitted the violation."14

In Amoco Oil Co. v. Environmental Protection Agency (Amoco I) ${ }^{15}$ these regulations were upheld over the challenge of the major oil coinpanies. The vicarious liability clause was, however, held invalid as embodying an irrebuttable presumption that all violations were the fault of the refiner. The court objected to the strict liability aspect of the regulation, and required that "refiners and distributors . . . have the opportumity to demonstrate freedom from fault."16

Taking the opimion in Amoco I into account, the EPA issued another version of the vicarious liability section. ${ }^{17}$ The new regulation allowed the refiner to relieve itself of hability for contanination caused by most other parties in the distribution network by showing that it had mcluded anti-contamination provisions in contracts with supplers, ${ }^{18}$ and that it had made "reasonable efforts" to imsure compliance with those provisions. ${ }^{19}$ The regulation retained, however, vicarious and strict liability for refimers who "substantially owned, leased, or controlled" the offending retail operation. ${ }^{20}$ It was with this aspect of the regulation that the court in Amoco II took issue.

Judge MacKinnon, writing for the majority, focused directly on the fact that the regulation held refiners vicariously liable for the negligent

11. 42 U.S.C. $\$ 1857 f-6 c$ (1970).

12. 40 C.F.R. $\$ 80.22$ (c) (1973).

13. 40 C.F.R. $\$ 80.22$ (b) (1973).

14. 40 C.F.R. $\S 80.23$ (a) (1) (1973).

15. 501 F.2d 722 (D.C. Cir. 1974). Environmentalists also challenged the EPA regulation. Natural Resources Defense Council, Inc. v. EPA, 512 F.2d 1351 (D.C. Cir. 1975), involved a successful effort to persuade the EPA to place more stringent restrictions on the quantities of lead in leaded gasoline.

16. 501 F.2d 722, $749^{\circ}$ (D.C. Cir. 1974); cf. Horne Plumbing and Heating Co. v. Occupational Safety \& Health Review Comm'n, 528 F.2d 564 (5th Cir. 1976) (holding that an einployer who has done everything reasonably possible to insure compliance with the Occupational Safety and Health Act of 1970, 29 U.S.C. $\S \S 660(a), 666(j)$ (1970), may not be held strictly liable for violations caused by the foremen).

17. 40 C.F.R. $\S 80.23$ (1975).

18. 40 C.F.R. $\$ 80.23$ (b) (2)(iii) (1975).

19. Id.

20. 40 C.F.R. $\S 80.23($ b) (2) (iv) (1975). 
conduct of their lessees without requiring any showing of actual responsibility for that negligence. The majority noted that at common law the hability of a lessor for the negligence of his lessee arose only after a finding at trial that the lessor had retained actual control of the premises during the term of the lease. ${ }^{21}$ By contrast, Judge MacKinnon argued that the challenged regulation presumed lessor control over the premises in all cases, and thus constituted a clear break with the common law. The court found the mere fact of a lease agreement to be inadequate to justify such a broad presumption. ${ }^{22}$ Reviewing the language of the enabling legislation, lie found that the statute did not authorize EPA, expressly or by implication, to alter common law rules of liability. ${ }^{23} \mathrm{He}$ argued that absent an indication of "a specific intent on the part of Congress to create a 'new tort'," the common law standard of liability must prevail over that establislied by the regulation. ${ }^{24}$ Because the disputed clause eliminated the common law's case-by-case determination of control, and because the majority felt that the evidence so weakly supported the EPA's presumption of such control, the court found that the regulation exceeded the EPA's granted authority. ${ }^{25}$ For that reason, Judge McKinnon concluded that the clause was "arbitrary . . . [and] not in accordance with law" under the APA. ${ }^{28}$

II

\section{ANALYSIS}

The court's decision is probably best understood as an expression of hostility toward federal regulation of large commercial enterprises.

21. 543 F.2d 270, 276 (D.C. Cir. 1976).

22 Id.

23. Id. at 275. The amendments provide that:

The Administrator may . . . control or prohibit the manufacture, introduction into commerce, offering for sale, or sale of any fuel or fuel additive .... if emission products of such fuel or fuel additive will impair to a significant degree the performance of any emission control device or system which is in general use .... .

42 U.S.C. $\$ 1857 \mathrm{f}-6 \mathrm{c}(\mathrm{c})(1)$ (1970).

24. Id.

25. Id. at 279.

26. Id. Section 706 of the Administrative Procedure Act (APA) provides that: The reviewing court shall ... (2) hold unlawful and set aside agency action, findings, and conclusions found to be-(A) arbitrary, capricious, an abuse of discretion, or otherwise not in accordance with law ... (C) im excess of statutory jurisdiction, anthority, or limitations, or short of statutory right . . . .

The court based its holding on the "arbitrary and capricious" clause, but the opmion's expressed concern with the problem of statutory authorization suggests that a holding based on the ultra vires clause would be more appropriate. There are very few cases overturning regulations on the basis of the ultra vires clause. Regulations are customarily upheld so long as they are reasonably related to the purposes of the enabling legislation. E.g., Mourning v. Family Publications Service, Inc., 411 U.S. 356, 369 (1973). 
Viewed in those terms, the result in the case is indefensible. There are, as well, two serious analytical objections to the decision. First, despite the court's concern with the protection of common law values, it failed to note that the regulation simply codified modern common law principles of liability. Second, the strict rule of delegation announced in the opinion would frustrate the fundamental rationales for legislative delegation of rulemaking authority.

\section{A Common Law Policies Underlying the Regulation}

The regulation struck down in Amoco II was designed to further the goal of rapid air quality improvement embodied in the 1970 Amendments to the Clean Air Act by encouraging oil refiners to closely inonitor the purity of unleaded gasoline. It is true that the regulation was stringent. The legislative history of the amendments, lowever, evidences congressional concern that progress toward improved air quality had been hampered by a lack of aggressiveness in the impleinentation of existing law. ${ }^{27}$ The vicarious liability provisions met this expressed need for more vigorous enforcement. Despite this congressional policy judgment, the court held that the common law rule of vicarious liability must control. It is difficult, however, to determine what common law interest the court was acting to save. On close examination the invalidated regulation appears to be founded on the same principles that underly the judge-made common law rules of vicarious liability.

Vicarious liability traditionally has been imposed to further two basic policies-risk prevention and risk allocation. ${ }^{28}$ Under the risk prevention rationale, liability attaches vicariously to those in control of the tortfeasor who could have lielped to prevent the harm. It is argued that the imposition of liability will motivate those in a position of control to exercise greater care or to force their agents to do so. ${ }^{29}$ Where the tortfeasor is an independent contractor or a lessee, however, courts have frequently refused to impute negligence to the principal. Oftentimes, the ground of decision in those cases is the principal's lack of control. ${ }^{30}$

Broader notions of public policy also influence the rules governing the liability of the principal. The most important example of this influence is the exception to the independent contractor rule in the case of non-delegable duties. Where a court finds that the relevant duty of due care is non-delegable, a principal inay be held liable for the neg-

27. H.R. REP. No. 1146, 91st Cong., 2d Sess., reprinted in [1970] U.S. CODB CONG. \& AD. NEWS 5356, 5360.

28. W. Prosser, The LaW of Torts $\$ 69$, at 459 (4th ed. 1971).

29. Id.

30. Id. § 71 , at 468 . 
ligence of the contractor despite the principal's imposition of reasonable safeguards and lack of control over the contractor. ${ }^{31}$ It is said that a duty is non-delegable when "the responsibility is so important to the commumity that the [principal] should not be permitted to transfer it to another."32 Examples of duties that have been held to be nondelegable include the duty of a railroad to fence its tracks properly, the duty of a municipality to keep premises safe for business visitors, and the duty of a landlord to make repairs according to a covenant. ${ }^{33}$ Both the generality of the policy underlying the creation of non-delegable duties and the heterogeneity among those that have been so designated illustrate the broad authority granted to common law courts to expand the liability of the principal where important policy goals intervene.

It is not unusual for lessee operators of refiner-owned stations to be treated as if they are independent contractors. In the context of ordinary negligence actions, this application of the employee-independent contractor distinction is well founded. Gas station operators lave been known to drop heavy objects on third parties, ${ }^{34}$ to allow grease to accumulate to sucl an extent that patrons slip, ${ }^{35}$ and to sell gasoline to mimors who later start fires. ${ }^{36}$ In these instances, case-bycase determination of whether the retailer's negligence ought to be imputed to the refiner is appropriate. As lessor, the refiner nnay have limited control over the activities causing the harm, particularly the hiring practices and station operations.

The regulations at issue in Amoco II hewed closely to the rationale of the independent contractor cases. Liability did not autoinatically attach for intentional mixing of leaded and unleaded gasoline by the retaile $^{37}$ or for retailer error in dispensing gasoline froin a pump containing leaded gas. ${ }^{38}$ Indeed, by limiting its presumption of vicarious liability to those situations where the refiner filled the three roles of

31. Id. at 470 .

32. Id. at 471 .

33. Id. at 470-71 (footnotes omitted).

34. Standard Oil Co. v. Soderling, 112 Ind. App. 437, 42 N.E.2d 373 (1943).

35. Standard Oil Co. v. Gentry, 241 Ala. 62, 1 So. 2d 29 (1941).

36. Grieving v. La Planta, 156 Kan. 196, 131 P.2d 898 (1942).

37. "[T]he refiner shall not be deemed in violation if ... the violation was caused by ... deliberate commingling of leaded and unleaded gasolime . . " 40 C.F.R. $\S 80.23(\mathrm{~b})(2)$ (ii) (1975).

38. In any case in which a retailer or his employee ... introduced leaded gasoline from a pump from which leaded gasoline is sold, dispensed or offered for sale, into a motor vehicle which is equipped with a gasoline tank filler inlet designed for the introduction of unleaded gasoline, only the retailer . . . shall be deemed in violation.

40 C.F.R. $\& 80.23$ (e) (1) (1975). 
owner, direct supplier and landlord, ${ }^{39}$ the regulation focused directly on those factors that tend to satisfy the common law requirement of control.

At company owned and supplied retail outlets, refimers exercise virtually complete control over the purity of unleaded gasoline distributed to their lessees. The crucial determinant of gasoline purity is the condition and operation of the distribution network itself. Unless a retailer accidentally or intentionally dispenses gasolime from a pump containing leaded gas, ${ }^{40}$ the introduction of contaminated fuel into an automobile requiring unleaded gasoline can only result from a flaw in the distribution system. The refiner usually owns and controls nearly all of the equipment used along the distribution route. ${ }^{41}$ Equally important, the refiner's employees are in control at most of the crucial stages of the distribution process. ${ }^{42}$ Both facts strongly suggest that the common law policy of fixing liability where there is control would dictate that the refiner be held vicariously liable for all contamination. ${ }^{43}$

It may be that the court saw the result in Amoco II as protecting the common law right to an individual determination of liability. As the non-delegable duty cases show, lowever, common law courts often fix liability regardless of actual control where important policy interests are at stake. The importance of air pollution control to the community is strongly evidenced by the massive legislative attempts to effectuate such control. Given the broad standards governing the establishment of non-delegable duties, this imterest arguably would justify a common law court in holding that the refiner's duty to assure that gasolime was uncontaninated was a non-delegable one. Even if the policy interest would not have justified the creation of a new non-delegable duty, it would clearly have been appropriate for the court to recognize the rele-

39. See note 3 supra.

40. EPA Proposed Restrictions, supra note 3, at 13,174. The EPA has established a system of nozzle designs that make it difficult to dispense gas from the wrong pump. 40 C.F.R. $\$ 80.22(f)$ (1976).

41. Decisions concerning the replacement of contaminated equipment and the modification or improvement of the retail facilities owned by the refiner are solely in the hands of the refiner. EPA Proposed Restrictions, supra note 3 at 13,174. The EPA found that:

[1] $\mathbf{n}$ the direct distribution chain, the branded refiners are making the decisions whether to adopt a three grade marketing system, installing a third pump and underground tank or whether to retain a two-grade marketing system, substituting unleaded gasoline for the leaded regular or premium grade. Where a branded refiner owns or leases a service station, the refiner makes the investment in new equipment.

Id. at 13,177 .

42. Id. at 13,175 .

43. The oil industry itself had recognized the degree of control that refiners maintain over gasoline purity. In a series of hearings before the Senate Subcoinmittee on the Judiciary, conducted in 1971 and 1972 to explore the desirability of divorcing refin- 
vance of factors other than control in determining the liability of gasoline refiners.

At common law problems of proof are also frequently considered in the design of liability rules. The doctrine of strict products liability results, at least in part, from judicial recognition that placing the burden of proof on the plaintiff will effectively defeat a claim in a complex industrial society. Similar considerations apply in the setting of the gasoline industry. Gasoline refining and distribution systems are coinplex and highly technical. Contamination within the system often results froin an accumulation of sinall impurities. ${ }^{44}$ Frequently contamination is caused by lead deposits in tanks, pipelines, and refinery facilities-deposits which derive from years of use of leaded fuel and which promise to contribute small amounts of contamination for years to come. $^{45}$ Accidental mixing of leaded and unleaded fuel is also common. Because the complexity of the system and the problein of cuinulative impact inake the source of contamination so difficult to detect, ${ }^{46}$ judge-made principles of strict enterprise liability, growing out of the doctrine of res ipsa loquitur, ${ }^{47}$ would shift liability to the entity best able to inomitor and police the systein-in this case, the refiner..$^{48}$

ers from control of their retail outlets, spokesmen for a number of major refiners emphasized the need to place responsibility for gasoline purity on the refiner. EPA Proposed Restrictions, supra note 3, at 13,176. A representative of Standard Oil of California, for example, stated: "It would be wholly unrealistic to expect service station dealers to have the technical competence and ability to undertake such quality contro1 . . . or expect them to return gasoline found to be substandard." Id.

44. EPA Proposed Restrictions, supra note 4, at 13,175.

It does not take much leaded gasoline to cause a batch of unleaded gasoline to exceed the standard. Only 100 gallons of leaded gasoline containing 2.5 grams of lead per gallon will add 0.025 gram of lead per gallon to a shipment of 10,000 gallons of unleaded product. If the shipmeut already contanis 0.03 gram of lead per gallon the delivered prodnct would then exceed the 0.05 standard when it reaches the retail outlet.

EPA Proposed Restrictious, supra note 3, at 13,175.

45. Amoco Oil Co. v. EPA (Amoco I), 501 F.2d 722, 726 (D.C. Cir. 1974).

46. This inability to identify actual parties at fault is due to the existence of processing agreements, the great complexity of the gasoline distribution system, and the fact that the contamination is a cumulative process which can both occur and be remedied at various stages of distribution. . . . If, for example, unleaded gasoline at a terminal coutains .045 gram of lead per gallon, it will probably exceed the .05 standard wheu it reaches . . . a retail outlet.

EPA Proposed Restrictions, supra note 4 at 13,175.

47. W. Prosser, The LAW OF ToRTS $\$ \$ 39,40$, at 221-35 (4th ed. 1971).

48. Vicarious liability as applied to defective products has witnessed recent expansion in a direction which suggests that courts might find liability in a situation such as that presented by Amoco II. The trend of this development has bcen to place liability on the manufacturer more often, the middlenian and retailer being seen as mere conduits for the flow of product from producer to consumer. See Prosser, The Fall of the Citadel, 50 Minn. L. Rev. 791 (1966). This is particularly true in situations where sophisticated testing is required to detect a contaminated product. For example, one court has stated that the retailer is under a duty "to discover and disclose defects which may be 


\section{B. Legislative Delegation of Authority}

The Amoco II opinion adopts a conservative approach to legislative delegation of the power to modify common law standards. In order to find express or implied authority in the enabling legislation, the majority would have required a showing that Congress harbored a "specific intent" to alter the precise common law rule in use. ${ }^{40}$ In shaping this requirement, the court apparently relied on the maxim that statutes in derogation of the common law are to be narrowly construed..$^{50}$ The majority apparently reasoned that this concern for the integrity of the coinon law supports a corollary rule liniting legislative grants of authority to alter the common law through the ruleinaking process. It is doubtful that the court's restrictive reading of the "narrow construction" rule harmonizes with the modern approach to renredial legislation. ${ }^{51}$ Whatever the inerits of the underlying rule may be, its extension to legislative delegation of power in the Amoco II opimion is contrary to both established precedent and sound regulatory policy.

The court's holding disregards substantial precedent allowing federal regulatory agencies to ignore common law rules when the inechanical application of those rules would defeat the legislative purpose. Thus, the Supreine Court lias held, for the purpose of establishing collective bargaining units, that the National Labor Relations Board inay designate as statutory "einployees" persons who at cominon law would have been held to be independent contractors. ${ }^{62}$ In other deci-

found by inspection alone, distinguished from dangers so concealed that mechanical or chemical tests are needed to disclose thenu." Kirk v. Steinway Drug Store Co., 38 Ill. App. 2d 415, 427, 187 N.E.2d 307, 312-13 (1963).

49. 543 F.2d at 275.

50. See, e.g., Robert C. Herd \& Co. v. Krawill Machinery Corp., 359 U.S. 297, 304, 305 (1959); Isbrandtsen Co. v. Johnson, 343 U.S. 779, 783 (1952).

51. Isbrandtsen Co. v. Johnson, 343 U.S. 779 (1952). The case relied upon by the Amoco II majority for the principle of narrow construction actually provides an example of a more liberal rule. That hitigation involved the construction of a federal statute, the Shipping Commissioners Act, 46 U.S.C. $\$ 604$ (1970), designed to protect seamen from the actions of their enployers. The defendant shipping coinpany had attempted to offset a claim for damages against the salary of the plaintiff seaman, an action allowed at common law but disfavored by the statute. In holding for the plaintiff, the Court stated: "The rule that statutes in derogation of the common law are to be strictly construed does not require such an adherence to the letter as would defeat an obvious legislative purpose or lessen the scope plainly intended to be given to the measure." 343 U.S. at 783, quoting Jamison v. Encarnacion, 281 U.S. 635, 640 (1930).

52. Goldberg v. Whitaker House Coop., 366 US. 28 (1961); Bartels v. Birmingham, 332 U.S. 126 (1947); United States v. Silk, 331 U.S. 704 (1947); Rutherford Food Corp. v. McComb, 331 U.S. 722 (1947); NLRB v. Hearst Publications, 322 U.S. 111 (1944); Mednick v. Albert Enterprises, Inc., 508 F.2d 297 (5th Cir. 1975). See also Clarkson Const. Co. v. Occupational Safety \& Health Review Comni'n, 531 F.2d 451 (10th Cir. 1976); Breman v. Gilles \& Cotting, Inc., 501 F.2d 1255 (4th Cir. 1974) (interpreting the word "employer"). 
sions the Court has allowed agencies to override state common law rules governing disregard of the corporate form in those situations where regulatory policies would thereby be promoted. ${ }^{53}$ In none of these cases did the Court focus on the issue of whether Congress imtended to alter the common law rule. Instead the opinions are based on the broad objectives of the relevant statute, ${ }^{54}$ the limited competence of the courts to review the proceedings of specialized agencies, ${ }^{55}$ and the need for national uniformity in the administration and application of federal law. ${ }^{56}$

Amoco II's requirement, that enabling legislation contain explicit authorization to alter specific common law rules, would tend to defeat the purpose of delegating rulemaking authority to regulatory agencies. Complex governniental functions imcreasingly force Congress to rely upon administrative agencies to shoulder the burdens of correspondingly conuplex rulenuaking. ${ }^{57}$ By bringing together experts with practical experience in the regulated field, the agency provides a superior technical forum..$^{58}$ Legislators cannot bring coinparable time or expertise to the solution of regulatory problenus. Judges liave even less to contribute to the process. At least one judge has suggested that even the minimal review of regulations allowed under the APA is beyond the coinpetence of the judiciary. ${ }^{59}$

The suggested intent requirement would hamstring this flexible approacli to regulation. To specify with sufficient precision the consmon law rules that each agency is authorized to modify, Congress would have to involve itself deeply in the minutiae of the regulated activity, displacing the judgment and expertise of the regulatory agency and

53. Sebastopol Meat Co. v. Secretary of Agriculture, 440 F.2d 983 (9th Cir. 1971); Joseph A. Kaplan \& Sons, Inc. v. FTC, 347 F.2d 785 (D.C. Cir. 1975); South Carolina Generating Co. v. Federal Power Comm'n, 261 F.2d 915 (4th Cir. 1958); Corn Products Refining Co. v. Benson, 232 F.2d 554 (2nd Cir. 1956); Keystone Mining Co. v. Gray, 120 F.2d 1 (3d Cir. 1941).

54. E.g., NLRB v. Hearst Publications, 322 U.S. 111, 128 (1944).

55. Id. at 123 .

56. Id. at 130.

57. See Wright, Court of Appeals Review of Federal Regulatory Agency Rulemaking, 26 AD. L. REv. 199, 200 (1974).

58. Id. at 201.

59. Court of Appeals review of regulatory agency decisions ... certainly taxes the generalist skills with which federal judges are said to be endowed.

...

... I must confess that on occasion I wish I had taken more math, science and economics courses.... For the records we receive sometimes ... leave in my mind only a confused sense of some vitally important, but successfully concealed purport, which it is my duty to extract, but which is within my power, if at all, only after the most inordinate expenditure of time.' Id. at 199-200 (footnotes omitted). 
undermining the ultimate rationale for delegation of rulemaking authority. It is hard to see how this considerable sacrifice in flexibility and efficiency is justified by the doubtful protection of common law interests afforded in the Amoco II opinion.

\section{CONCLUSION}

By extending the "arbitrary and capricious" clause of the Administrative Procedure Act to limit agency rulemaking that conflicts with common law doctrines, the court in Amoco II struck out in a direction that threatens the rationality of the regulatory process. Formalist reliance on common law rules may hinder regulatory policy without protecting any substantive legal interests. The "specific intent" requirement for delegation of rulemaking authority undercuts the central rationale of legislative delegation. For these reasons, prior cases detailing the relationship between agencies and the courts have generally refused to hold the common law supreme in situations where the agency is acting in a inanner consistent with legislative policy. The Amoco II decision is an unwise departure from the sound reasoning of those cases, and should not be followed.

Alan Waltner*

* A.B. 1974, University of California at Berkeley; third year student, Boalt Hall School of Law. 